\title{
Occurrence and survival of pathogens at different sludge depths in unlined pit latrines in Kampala slums
}

\author{
Sylivia Nabateesa',2, Ahamada Zziwa', Isa Kabenge', Robert Kambugu', Joshua Wanyama' and Allan John Komakech' \\ 'Department of Agricultural and Bio-systems Engineering, Makerere University, P.O. Box 7062, Kampala, Uganda \\ ${ }^{2}$ National Water and Sewerage Corporation. PO Box 7053, Kampala, Uganda
}

\begin{abstract}
Occurrence and survival of pathogens in faecal sludge was investigated in unlined pit latrines at varying depths in peri-urban areas of Kampala city, Uganda. A total of 55 unlined pit latrines, 7 private and 8 rental unlined pit latrines were sampled in the first and second phases (representing the rainy season) and 40 pits in the third phase (representing dry season), and analysed for indicator organisms and pathogens from 4 pit latrine sludge layers, at depths of $0,0.5,1.0$ and $1.5 \mathrm{~m}$, following APHA standard methods. Physico-chemical parameters of the faecal sludge were also measured. Three sampling phases were undertaken to determine the effect of seasonal variation. Results indicate that the mean temperature and $\mathrm{pH}$ were $25.4 \pm 1.14^{\circ} \mathrm{C}$ and $8.0 \pm 1.5$, respectively; and moisture content increased with pit sludge depth, except between Depths 3 and 4 . Average moisture content was $86.3 \pm 3 \%$. The measured parameters varied significantly $(P>0.05)$ between seasons. The mean reduction in total coliforms, thermo-tolerant coliforms, $E$. coli, and faecal enterococci with sludge depth was significant at all depths $(P<0.05)$, but the least significant difference was not significant at depth levels of $1.0 \mathrm{~m}$ and $1.5 \mathrm{~m}$. Salmonella was only detected at the top layer of faecal sludge in $60 \%$ of Phase 2 samples and in only $20 \%$ of the samples in Phase 3 . About $200-4100$ eggs/g of strongyles were found in $98 \%$ of the samples and $100-1600$ eggs/g of ascarids in $55 \%$ of the samples. Temperature, $\mathrm{pH}$ and moisture content did not show a significant correlation with observed reductions of indicators and pathogens. With extrapolation of the generated regression models, a pit of $8 \mathrm{~m}$ can be recommended for reduction of bacteria. It is recommended that protective field gear be used during pit emptying and that faecal sludge treatment should be done to reduce pathogens before disposal into the environment.
\end{abstract}

Keywords: pathogens, indicator organisms, faecal sludge, unlined pit latrine, water contamination

\section{INTRODUCTION}

Access to appropriate sanitation facilities is a major global challenge today, with over a third of the world's population still lacking access to improved sanitation (WHO and UNICEF, 2015). Uganda has a population of 34.5 million, growing at an estimated rate of $3.25 \%$ per annum (UBOS, 2014). Kampala, Uganda's capital city, hosts a third of the country's urban population (Trading Economics Statistics, 2012). Kampala, being an urban agglomeration with a daytime population of over 2.5 million people (UBOS, 2014), suffers health and environmental problems related to the increasing population pressure. In the peri-urban communities with informal settlements, land is subdivided into very small plots of less than $300 \mathrm{~m}^{2}$, leading to several households sharing pit latrines of shallow depths owing to limited space. It has also been reported that some on-site sanitary interventions have become a threat to groundwater-derived domestic supplies, mainly because of pollution and contamination (Sorensen et al., 2016). This is also the case in Kampala slums, with inadequate water and sanitation facilities resulting in people using poorly-constructed shared pit latrines which are a pollution risk to groundwater, especially where the water table is high. Hence poor sanitation and faecal sludge management have negative impacts on human health through contamination and pollution of water sources and food sources (Rose et al., 2015). The risk of groundwater contamination is even higher in the densely populated areas (Dzwairo et al., 2006). This has resulted in water and

\footnotetext{
To whom all correspondence should be addressed.

e-mail: engzziwa@gmail.com

Received 12 April 2016; accepted in revised form 9 October 2017
}

sanitation related diseases being among the top 10 killers in Uganda, especially in urban informal settlements (Kibikyo and Kakembo, 2010), and this has been partly attributed to use of contaminated groundwater.

It is evident that access to effective sanitation in Kampala is limited and it does not cope with urbanization and industrial development in the city. Less than $8 \%$ of Kampala residents are currently served by the public sewer system (African Water Facility, 2012) with the majority relying on various forms of on-site sanitation - that is $51.7 \%$ use septic tanks while $38.2 \%$ rely on pit latrines (Zziwa et al., 2014). The situation is compounded by weak national policies and regulatory frameworks regarding faecal sludge management, a common feature in most sub-Saharan African countries (Holm et al. 2015).

Pit latrines are used as anaerobic accumulation systems for stabilizing faecal matter, urine and other added materials (Chaggu, 2004), but they also serve as containment for digestion of fresh faeces and storage of the digested faecal solids (Mara, 1996). In addition, pits fill at different rates owing to user diets and behaviour (Brouckaert et al., 2013). For instance, most pits in Kampala double as faecal and waste disposal points. Due to the functionality of on-site sanitation facilities, there is a challenge of pit latrines filling prematurely; yet the limited size of residential plots, particularly in Kampala, does not allow for a new pit to be dug (Zziwa et al., 2016).

This scenario necessitates emptying of the existing pits and finding safe means of disposing of the sludge (Yoke et al., 2009). However, the emptying and disposal of pit sludge has become a challenge, partly due to the congestion of slum settlements, inaccessibility of residences due to poorly-planned access-road networks and unplanned sanitation systems (Thye et al., 2009; Radford and Fenner, 2013). The most common practice is disposal of the sludge to wastewater treatment plants using vacuum 
trucks. However, introduction of pit sludge into wastewater works and waste stabilization ponds increases the risk of wastewater treatment plant failure. The fact that pit latrines display incomplete anaerobic digestion (Nwaneri, 2009), the non-homogeneity in pits within the same locality and incomplete pathogen die-off (Buckley et al., 2008), imply that there are still water- and sanitation-related challenges which necessitate scientific research and development. Investing in and developing scientific research in pit latrine content characterization is therefore a pivotal contribution towards sustainable handling and disposal of sludge. Therefore, this paper investigated the factors which influence safe pit latrine emptying, particularly the occurrence and survival of pathogens at different sludge depths in unlined pit latrines of Kampala slums.

\section{MATERIALS AND METHODS}

\section{Description of the study area}

Kampala is located on hilly terrain at an altitude of about $1300 \mathrm{~m}$ amsl, on the north shore of Lake Victoria, and receives a mean annual rainfall of $1200 \mathrm{~mm}$. The climate is tropical wet (April to June and September to December) and dry (January to March and July to August) (UN-Habitat, 2010). The topography of the city is characterized by a series of low-lying hills with flat hilltops. These hills are surrounded by a network of wetlands which have been developed into informal settlements. As a consequence, these areas have no access to the central sewerage system and thus experience many sanitation challenges. Sanitation-related diseases such as diarrhoea, dysentery and cholera are common in the area, with the highest prevalence occurring in children below 5 years (Katukiza et al., 2010). However, these opportunistic diseases could be prevented with good hygiene and sanitation practices (Kulabako et al., 2010). Administratively, Kampala is divided into 5 divisions: Kawempe, Rubaga, Makindye, Nakawa and Central (Fig. 1).

\section{Study design}

This study was carried out in 3 phases to capture the impact of season on the parameters investigated. A total of 15 unlined pit latrines were sampled in the rainy season and 40 in the dry season. In September 2014 (first phase), 15 unlined pit latrines were selected and sampled: 8 rental pit latrines (single pit used by several households but limited to only those households) and 7 private pit latrines (used by single household). This number of latrines was adopted from previous studies by Nwaneri, (2009), Buckley et al. (2008) and Bakare et al. (2012), who characterized pit latrine sludge from 16 lined and unlined pit latrines. To make a comparison within the season, these same pit latrines were re-sampled in December 2014 (second phase). The average monthly rainfall between September and December 2014 was $84.4 \mathrm{~mm}$ (Accessed at http://www.accuweather.com). In February and March 2015 (Phase 3), 40 more pit latrines were sampled to make a total of 55 unlined pit latrines. The average monthly rainfall between February and March 2015 was $39.4 \mathrm{~mm}$ (Accessed at http://www.accuweather.com). The sampled pit latrines were located in low-lying areas of Kampala $(\approx 1200 \mathrm{~m}$ amsl) because it is these areas that face the biggest challenge with sanitation.

\section{Sample collection}

Ethical clearance and research approval were obtained from Kampala Capital City Authority and Uganda National Council for Science and Technology prior to sample collection. Samples were collected from slums most affected with sanitation challenges at spatially distributed locations within Kampala (Fig. 1). A specially designed sludge sampler (Fig. 2) was used to collect sludge samples. Four samples were collected from each pit latrine at four sludge depths $(0.0 \mathrm{~m}, 0.5 \mathrm{~m}, 1.0 \mathrm{~m}$, and $1.5 \mathrm{~m})$. Temperature and $\mathrm{pH}$ of samples were determined on-site by inserting the probe into the sample immediately after sampling. Samples were wrapped in black polyethylene bags to mimic dark conditions of a pit latrine and later put in a portable ice chest for transportation to the laboratory. Samples were tested within 1 day after sampling to avoid re-growth of some bacteria (Sherpa et al., 2009).

\section{Physico-chemical parameters}

The physico-chemical parameters measured in this study were temperature, moisture and $\mathrm{pH}$, because these are the major determinants of pathogen survival. Temperature and $\mathrm{pH}$ readings were taken at the time of sample collection for each layer using a digital $\mathrm{pH}$ meter (HI 98128 Hanna Instruments Limited, Bedfordshire, UK). Moisture content was determined using the oven-dry method following APHA (1999).

\section{Indicator organisms and pathogen analysis}

Total coliforms (TC), thermo-tolerant coliforms (TTC), E. coli, faecal enterococci and Salmonella were determined to infer bacterial pathogen die-off patterns in pit latrine sludge. From a well-homogenized sample, $5 \mathrm{~g}$ was weighed into a sterile stomacher and $45 \mathrm{~mL}$ of peptone water was added and blended. Serial dilutions up to $10^{-6}$ were performed. E. coli and TC were cultured on chromocult coliform agar (CCA, Merck Dermstadt, Germany), and enterococci on Slanetz and Bartley agar (Oxoid, England), thermo-tolerant coliforms on violet red bile agar (Pronadisa, Spain), and Salmonella on xylose lysine dextrose (XLD) agar. Enumeration of E. coli, TC, TTC, enterococci, and Salmonella colonies was performed according to Byamukama et al. (2005). For Salmonella, bio-chemical tests were performed; $5 \mathrm{~g}$ of pit sludge was weighed from a well-mixed sample using an analytical balance and transferred to $45 \mathrm{~mL}$ of peptone water in a stomacher for blending and incubated at $37^{\circ} \mathrm{C}$ for $24 \mathrm{~h}$. On Day $2,1 \mathrm{~mL}$ from the pre-enriched sample was transferred to $9 \mathrm{~mL}$ of Selenite Broth at $42^{\circ} \mathrm{C}$ for $24 \mathrm{~h}$.

On Day 3, a loop full was striped on the XLD agar and incubated at $37^{\circ} \mathrm{C}$ for $24 \mathrm{~h}$ and formed pink colonies with a dark centre. On Day 4, biochemical tests were performed with urease while on Days 5 and 6; TSI and citrate were used. Urea agar slant (slope) was inoculated and incubated at $37^{\circ} \mathrm{C}$ for $1-4 \mathrm{~h}$ following APHA (1999). The urease-negative samples were inoculated on TSI slant and on Day 5 incubated at $37^{\circ} \mathrm{C}$ for $24 \mathrm{~h}$, and thereafter inoculated on citrate. Helminth ova were determined following criteria used by Hawksworth et al. (2005). Approximately $3 \mathrm{~g}$ of faecal sludge was weighed and dissolved into $45 \mathrm{~mL}$ of distilled water in a beaker. The solution was filtered using a sieve to make a filtrate into a $45 \mathrm{~mL}$ conical centrifuge tube. The tube was then centrifuged at $2000 \mathrm{r} / \mathrm{min}$ for $2 \mathrm{~min}$ and the supernatant discarded. The sediment was topped up with a saturated solution of sodium chloride to the mark of $45 \mathrm{~mL}$ while vortexing. The saturated solution of sodium chloride has a high specific gravity which allows all of the viable eggs to float. The solution obtained was pipetted onto a MacMaster microscope slide for examination using the compound microscope at objective magnification 10 and the eggs were counted. 


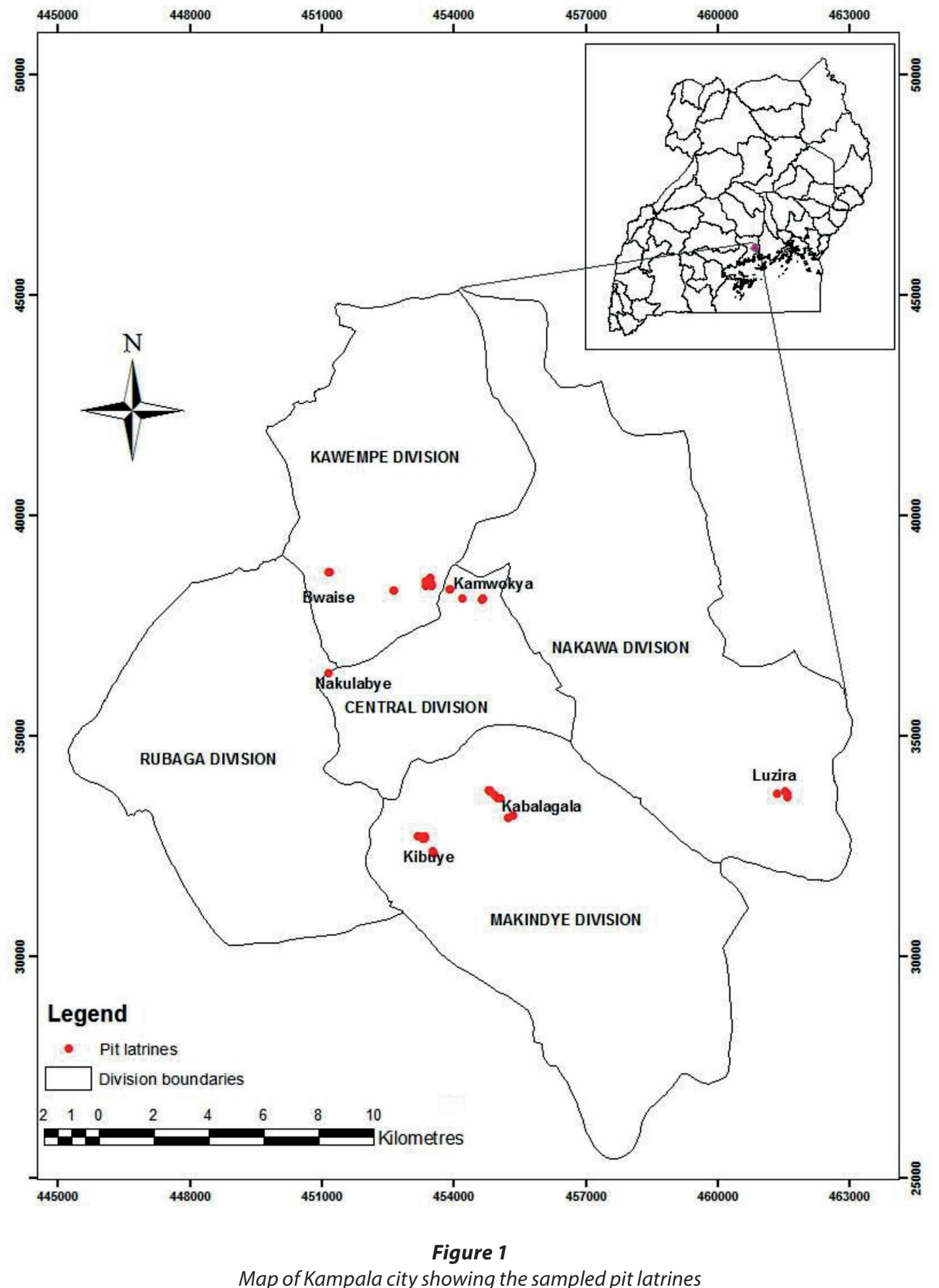

\section{Statistical analysis}

GenStat Discovery Edition 4 was used for statistical analysis. One way analysis of variance (ANOVA) was used to determine the statistical differences in the concentration of various parameters in the pit latrine sludge at different depths at a 95\% confidence level. Following analysis of variance, multiple comparisons using least significant difference (LSD) were done to establish which parameters were significantly different based on the LSD. The correlation between the physico-chemical properties and the bacterial load reduction was also established. Linear regression of log-transformed data for the bacterial load was also performed to show the trends of reduction in bacteria.

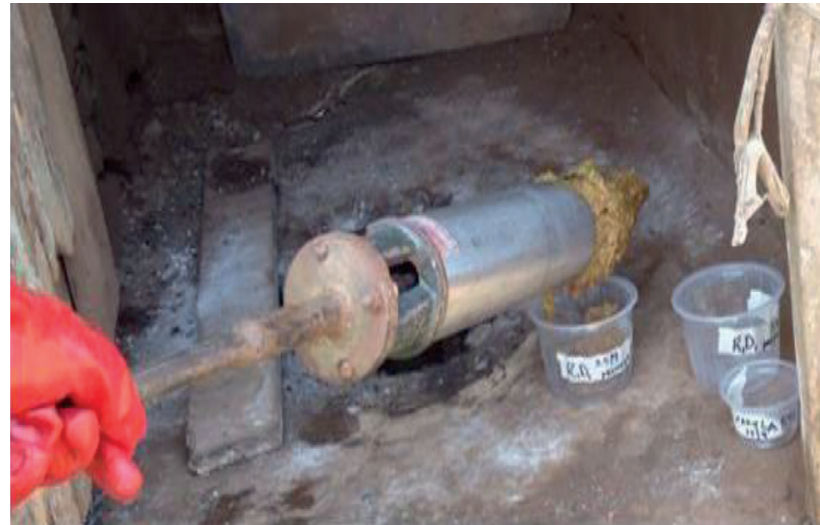

Figure 2

Pit latrine sludge sampling using a sludge sampler 


\section{RESULTS AND DISCUSSION}

\section{Physio-chemical properties of pit latrine sludge}

\section{Temperature}

The overall average temperature in the sampled pit latrines was $25.4^{\circ} \mathrm{C}$ with a range of $22.3-30.7^{\circ} \mathrm{C}$. The temperature results from this study were in agreement with those reported by Sherpa et al. (2009), of $19.5-32.8^{\circ} \mathrm{C}$ in urine-diverting toilets with ash addition. Temperature varied significantly $(P<0.05)$ with the pit sludge depth but there was no significant difference $(P>0.05)$ between the two sampling phases of September and December (Figure 3a and Fig. 2b), implying that pit latrine contents' temperature is relatively constant; thus Phase 1 and 3 were combined to generate more generalized trends. There was no significant difference $(P>0.05)$ in temperatures between private and rental pits in the two phases (Figure $3 \mathrm{a}$ and $3 \mathrm{~b}$ ), implying that pit latrine user category does not affect the temperature of the contents. As a result, pit category was not considered in analysis of the third phase results. The temperature is higher in the top layer for both private and rental pit latrines and decreases with depth of the pit (Fig. 2c). This could be because of the increasing moisture content with depth which causes the cooling effect. Therefore, the measured temperature of pit sludge at all sampled layers favours survival of pathogenic organisms since it falls within the mesophilic temperature range of $20^{\circ} \mathrm{C}$ to $45^{\circ} \mathrm{C}$, at which these pathogens thrive (Buckley et al., 2008; Strande et al., 2014)

\section{Moisture content}

Moisture content ranged from $60-99 \%$ for all layers of sampled pits and was significantly different $(P<0.05)$ between pit layers sampled. There was no significant difference between moisture content of sludge from private and rental pits in the two phases (1 and 2) (Figs $4 \mathrm{a}$ and $\mathrm{b}$ ). A slight increase in moisture content from the first level to the second, a large rise to the third depth and a fall at the fourth depth was observed (Fig. 4c). Nwaneri (2009), Bakare et al. (2012) and Still and Foxon (2012) reported increasing trends of moisture content in unlined pit latrine sludge for pits located in high water table areas, and decreasing trends of moisture content in pits situated in low water table areas. This suggests water ingress from the groundwater into the unlined pit latrines. This can further be explained by a high water table in the slums within the study area, as reported by Kulabako (2005).

According to Bakare et al. (2012), moisture content above $50 \%$ provides a suitable environment for microbial activity. Therefore, each layer in the sampled pit latrines can support microbial activity. Since most of the peri-urban dwellings are situated in areas with high water tables, contamination of groundwater is inevitable where unlined pits are commonly used. Further, moisture content increased with depth of the pit sludge, an indication of ingress of water into the pits. Communication of groundwater sources with pits, which have been established to harbour pathogenic organisms, poses a risk to peri-urban dwellers who depend on water sources situated in close proximity to pits. Moisture content at the $1.5 \mathrm{~m}$ depth was observed to decrease, which is against the general trend. The decrease in moisture content at this level could have been a result of accumulation of stabilized non-biodegradable organics and inorganics (Buckley et al., 2008). Furthermore, the high moisture content observed (60 to 99\%) could have contributed to the low temperature in the pit latrine sludge due to the cooling effect.
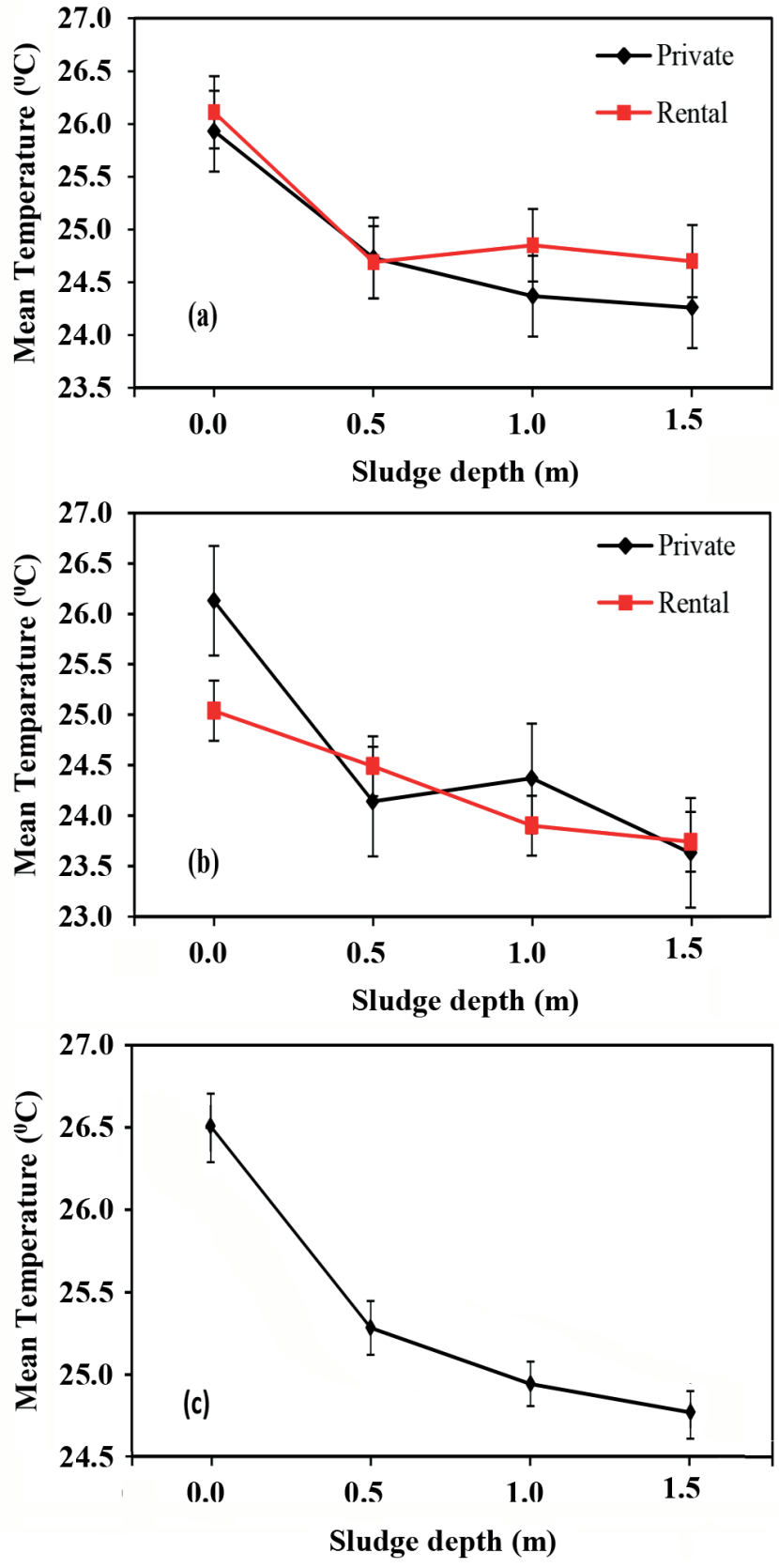

Figure 3

Trend of mean temperature for faecal sludge sampled from 4 different layers (depth) within the pit latrine for Phases 1 (a), 2 (b) and 3 (c). Error bars represent standard error of the mean.

\section{pH}

Generally, $\mathrm{pH}$ of the pit contents varied from pit to pit as observed by Rose et al. (2015), who argued that faecal pH varies with user diets. In the first phase, the $\mathrm{pH}$ of the sludge top surface was slightly below neutral (Figure 55a). In Phase 2 , the contents were alkaline with $\mathrm{pH}$ above 9 (Figure 55b). Further, the top layer had a mean $\mathrm{pH}$ of $7.1 \pm 1.2$, which is near the 7.5 reported by Lopez Zavala et al. (2002) for fresh human faeces. The $\mathrm{pH}$ of FS from septic tanks usually ranges from 6.5 to 8.0 (Ingalinella et al., 2002; Cofie et al., 2006), but can also fluctuate greatly from 1.5 to 12.6 (USEPA, 1994). The wide variation of $\mathrm{pH}$ is a result of many processes occurring 

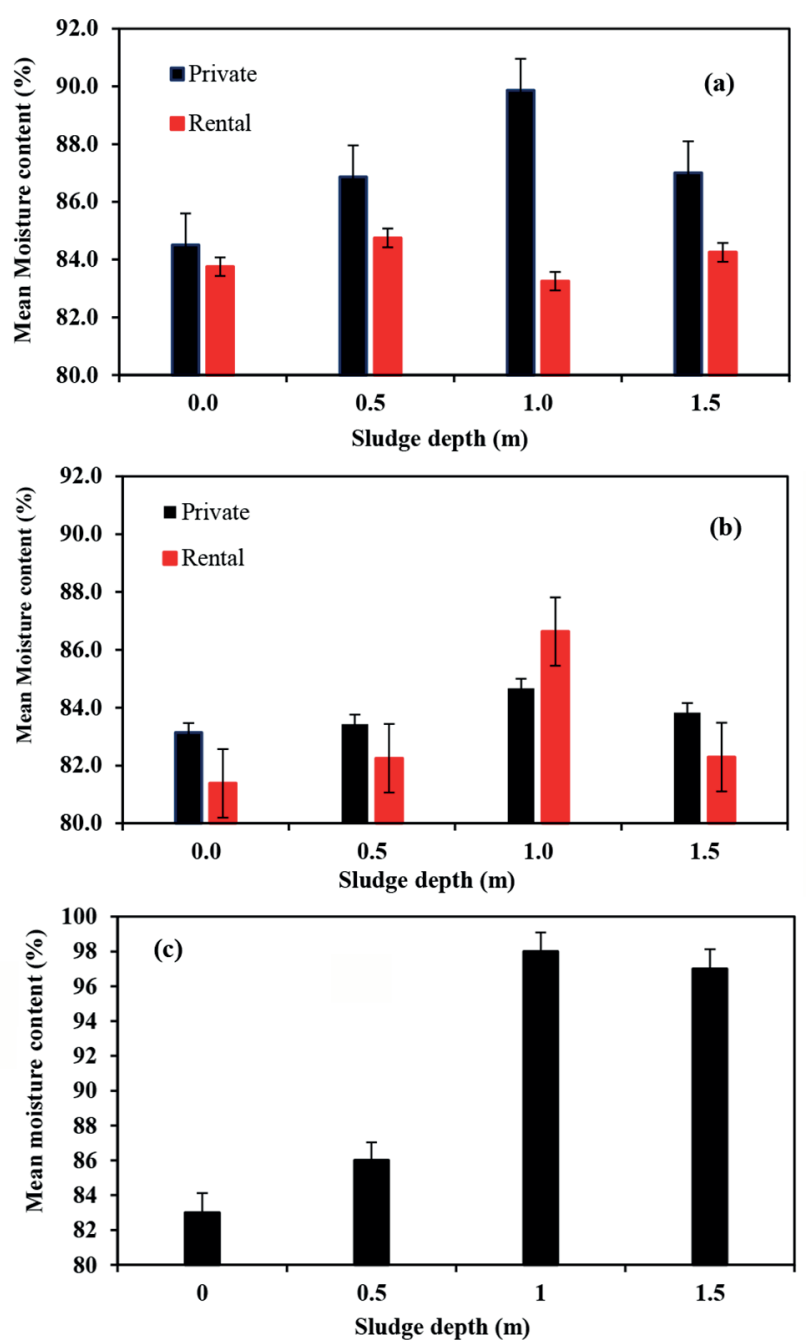

Figure 4

Mean moisture content for faecal sludge sampled from 4 different layers (depths) within the pit latrine for Phases 1 (a), 2 (b) and 3 (c). Error bars represent standard error of the mean.

in the pit latrines. These processes include the consumption and release of ammonia, the production and consumption of volatile fatty acids, the release of sulphide due to the reduction of sulphate and sulphite and the conversion of neutral carbonaceous organic carbon to methane and carbon dioxide (Nwaneri, 2009). The $\mathrm{pH}$ of rental and private pit latrines was not significantly different at 3 sampling depths, as evidenced by errors bars crossing each other on Figure 55a and $5 \mathrm{~b}$. There was a significant statistical difference between the $\mathrm{pH}$ values at the different sludge depths. This could be attributed to different anaerobic processes occurring in the different layers of the pit latrine. For instance, consumption of volatile fatty acids by methanogens reduces $\mathrm{pH}$, depending on the equilibrium between methanogens and acidogens. Figure $55 \mathrm{c}$ shows Phase 3 results, which showed an increase from the top layer to a depth of $0.5 \mathrm{~m}$ and remained almost constant to the fourth depth. The mean difference in $\mathrm{pH}$ was significant between the $0.0 \mathrm{~m}$ depth and other depths but insignificant at the other depths.
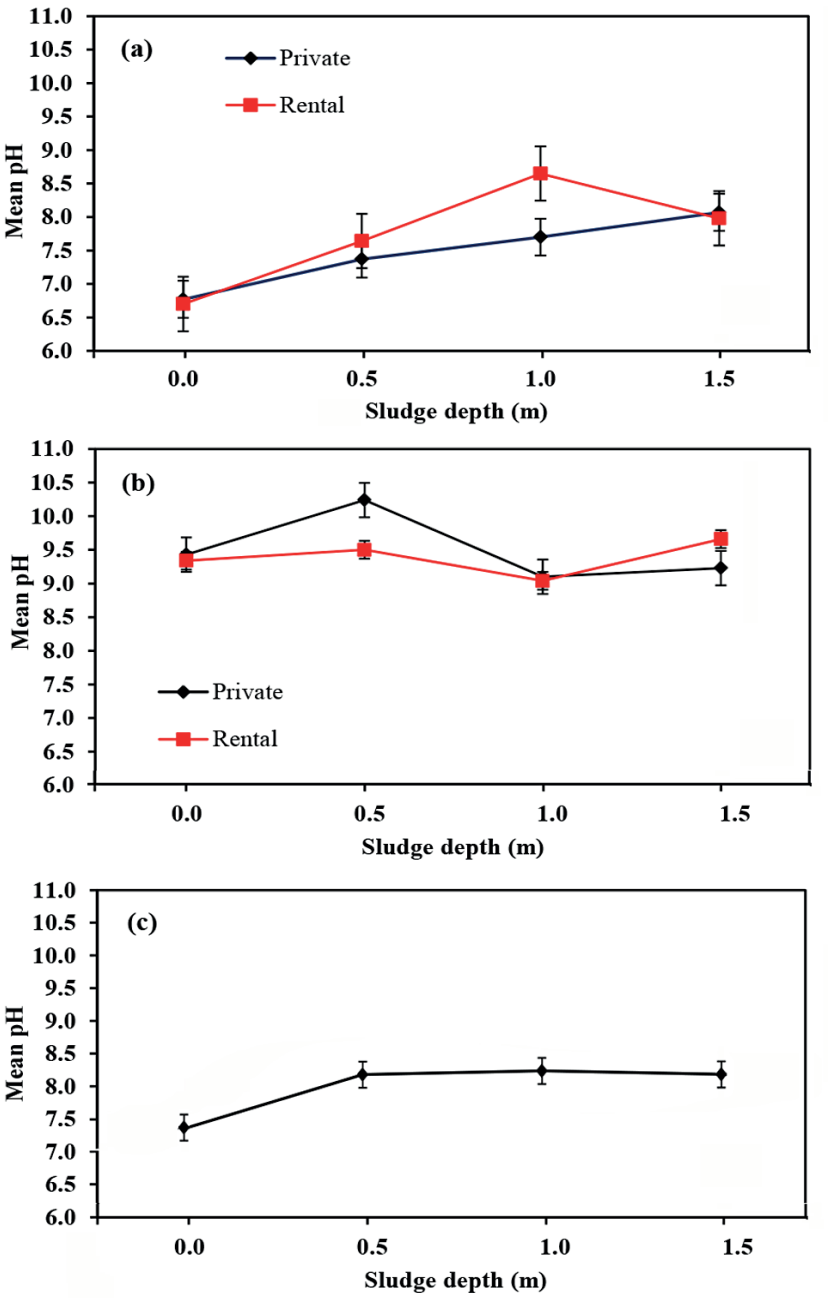

Figure 5

Trend of mean $\mathrm{pH}$ for faecal sludge sampled from 4 different layers (depth) within the pit latrine for Phases 1 (a), 2 (b) and 3 (c). Error bars represent standard error of the mean.

\section{Pathogen load in the pit latrine sludge}

\section{Reduction trends of bacterial loads}

The reduction of the bacterial count with depth was significant. The log count of total coliforms, thermo-tolerant coliforms, E. coli, and faecal enterococci are shown in Figure 66. Total coliforms showed the highest prevalence at Levels 1 and 2, and at Levels 3 and 4 faecal enterococci showed a greater prevalence. E. coli and thermo-tolerant coliforms showed values in the same range. The least significant difference for the mean of $\log$ TC, TTC, E. coli and faecal enterococci was $0.285,0.285,0.328$ and 0.298 , respectively, with the third and fourth depths showing an insignificant difference between TC, TTC, E. coli and faecal enterococci. Bakare et al. (2012) reported that if the rate of reduction of COD concentration, the fraction of volatile solids and biodegradability are assumed to be constant over the sludge residence time in the pit, then the linear fit from the study suggests that Layer III extends to approximately $1 \mathrm{~m}$ below the surface of the pit. The bacterial analyses agreed with this 
hypothesis, with a mean separation at depths of $1 \mathrm{~m}$ and $1.5 \mathrm{~m}$ being insignificant. Pit sludge samples in Phase 1 did not have Salmonella, implying that the pit latrine users did not have typhoid during that time. In Phase $2,60 \%$ of the pits had Salmonella, which corresponded to an outbreak of typhoid in the study area (WHO and UNICEF, 2015). Salmonella spp. were only present at the surface because they survive well in aerobic conditions which can only be achieved in the top layer, due to obstruction of oxygen by the fresh sludge that comes into the pit (Kimuli et al., 2016), and their survival period is 5 days in tropical environments (Strauss, 1994). About 20\% of pits sampled in Phase 3 had Salmonella in the top layer.

Pathogen loads in the pit sludge were found to decrease down the pit (Figure 6 6, Table 1). Strande et al. (2014) argued that as anaerobic processes become more intense, temperatures of the pit sludge become more hostile for the survival of pathogens; hence their die-off. However, temperatures observed from sampled pits $\left(22.3-30.7^{\circ} \mathrm{C}\right)$ were uniquely below the lethal temperature $\left(45^{\circ} \mathrm{C}\right)$ for pathogens. This suggests that temperature could not have been the key determinant for the decreasing trends. Residence time of the sludge in sampled pits could explain the decrease since the pathogens eventually die off in the bottom layer due to depletion of the nutritional content and thus sustaining ability of stabilized faecal matter down the pit, as noted by Buckley et al. (2008). The observed decreasing amounts of bacterial pathogens implies that extra care has to be taken to protect pit emptiers, especially when emptying the top layers of faecal sludge as this layer has the highest amounts of bacterial pathogens.

Furthermore, the major factors affecting the die-off of microorganisms in the faecal sludge, like temperature, $\mathrm{pH}$ and moisture content, were not in the optimal range for sanitization of the pit sludge. Therefore, die-off of pathogens was not due to a single chemo-physical parameter but a combination of these factors that could have caused the general decrease in pathogenic loads as evidenced by the combined correlation between the bacteriological and the chemo-physical parameters investigated (Table 2). Peasey (2000) and Austin (2001) similarly observed that no single factor can affect the die-off of microorganisms in pit latrine sludge but rather a combination of many factors. It should be noted that there was a significant positive correlation between indicator organisms and pathogens (Table 2). The re-growth activities cannot be ignored, though the explanation for this strong correlation can be given by the availability of nutrients (Kimuli et al., 2016), which could have contributed to lower die-off rates due to more favourable conditions for survival.

The relatively high levels of TC compared to E. coli and TTC can be deduced from the lower reduction rate from the simple regression analysis. TC tends to remain viable with higher moisture and low $\mathrm{pH}$. Treatment methods that aim at reducing moisture and increasing $\mathrm{pH}$ should be sought. Methods like sun drying, addition of ash and desiccation can be used. However, the use of E. coli and TC as a measure of sanitization of faecal sludge is debatable due to their relatively short survival time in the environment and not being able to indicate for more resistant pathogens (Höglund, 2001). Thus, in this study, TC was used to predict the presence of the coliform group of bacteria; TTC were used to predict heat-persistent pathogens and E. coli has some strains which are pathogenic.

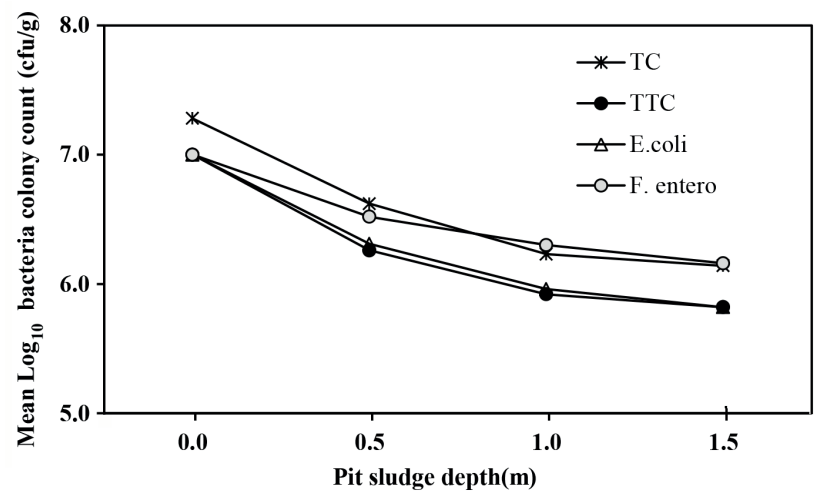

Figure 6

Reduction of bacterial pathogens with pit sludge depth

\begin{tabular}{|l|c|c|c|c|c|}
\hline \multicolumn{7}{|c|}{ TABLE 1} \\
\hline Pathogen/indicator & $n$ & Log10 per $\mathrm{m}, X$ & Sig. $X$ & $\boldsymbol{D}$ & Sig. $\boldsymbol{D}$ \\
\hline TC & 220 & -0.7639 & $P<0.001$ & 7.1420 & $P<0.001$ \\
\hline TTC & 220 & -0.7477 & $P<0.001$ & 6.8092 & $P<0.001$ \\
\hline E. coli & 220 & -0.7990 & $P<0.001$ & 6.8832 & $P<0.001$ \\
\hline ENT & 220 & -0.5048 & $P<0.001$ & 6.8377 & $P<0.001$ \\
\hline
\end{tabular}

$\mathrm{X}$ - slope, D - deviation from 0 at depth 0 , Sig. X -significance of the slope, Sig. D -significance of deviation, $\mathrm{n}$-replicates

\begin{tabular}{|l|c|c|c|c|c|c|}
\hline \multicolumn{7}{|c|}{ TABLE 2 } \\
\hline Spearman's $\left(\boldsymbol{r}_{\boldsymbol{s}}\right)$ half matrix. The underlined values indicate strong correlation. \\
\hline $\mathrm{pH}$ & $\mathrm{pH}$ & Temp & MC & Log TTC & Log E.coli & Log entero \\
\hline Temp & 1.00 & & & & & \\
\hline $\mathrm{MC}$ & -0.22 & 1.00 & & & & \\
\hline Log TTC & -0.07 & -0.24 & 1.00 & & & \\
\hline Log E. coli & -0.24 & 0.24 & -0.17 & 1.00 & & \\
\hline Log entero & -0.23 & 0.23 & -0.13 & $\underline{0.85}$ & 1.00 & \\
\hline Log TC & -0.16 & 0.09 & -0.18 & $\underline{0.62}$ & $\underline{0.64}$ & 1.00 \\
\hline
\end{tabular}


Enterococci are considered to be a better indicator for more resistant faecal bacteria than the TC due to its greater resistance. Höglund (2001) suggested that faecal enterococci can be used as an indication of the presence of viruses. The observed lower die-off rate for enterococci in the present study, of -0.5 (Table 1) with depth, could therefore be an indication of potential survival of more resistant enteric pathogens. The conditions in the studied pit latrine systems were not appropriate for their sufficient reduction, with the moisture content being very high and the $\mathrm{pH}$ generally below 9. Based on an extrapolation using the regression models developed (Table 1), a pit depth of $8 \mathrm{~m}$ would be appropriate to render the pathogens inactive, but in the slum setting in Kampala the water table is very high (Kulabako et al., 2005) and such a depth cannot be attained.

About $98 \%$ of the samples analysed had strongyles in the range of 200 to 4100 eggs/g wet sample. Almost 55\% of the samples showed ascarids in the range of 100 to 1600 eggs/g wet sample, of these, $7 \%$ were typical Ascaris lumbricoides. This is because at all depths sampled, temperatures were within the favourable range for their survival. Therefore, any mechanism that can increase pit sludge temperature would be an effective means of treating FS. In Hawksworth et al. (2010), the effect of relative humidity and temperature on the die-off rate of Ascaris ova in the urine diversion waste was investigated. Temperatures above $60^{\circ} \mathrm{C}$ were found to be optimum for the complete die-off of Ascaris ova in a short time $(24 \mathrm{~h})$. High temperatures increase the rate of desiccation and cell rupture. This is in agreement with a study done by Pecson et al. (2007), who found that helminth ova die-off was dependent on temperature. It was also noted by Hawksworth et al. (2010) that at temperatures below $60^{\circ} \mathrm{C}$ relative humidity becomes a critical factor. Konë et al. (2007) noted that $45^{\circ} \mathrm{C}$ is the lethal temperature for Ascaris eggs.

\section{CONCLUSION}

The pit latrines studied had low temperatures, high moisture content and alkaline $\mathrm{pH}$, averaging $25.4^{\circ} \mathrm{C}, 86.3 \%$ and 8.0 , respectively. Measured values of the temperature, moisture content and $\mathrm{pH}$ were within ranges suitable for survival and sustained thriving of pathogenic organisms in the pit sludge.

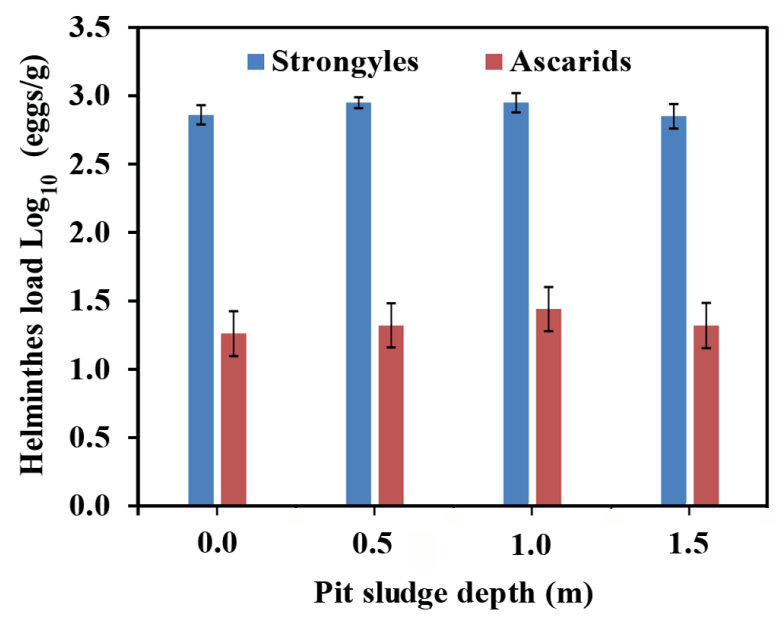

Figure 7

Helminth distribution for faecal sludge sampled from different layers of unlined pit latrines
The existence of favourable conditions for microbial activity explains their occurrence in all layers of the pit sludge. It was established that pathogens occur at all depths although the loads decrease down the pit. This implies that sludge from various levels within a pit latrine has to be handled with care due to its pathogenic nature. In addition, the high detection rates and numbers of helminth eggs in the pit latrine sludge imply that there is a high potential for faecally-transmitted parasitic diseases in the areas sampled as well as those in similar settings. The pathogen load profile determined reinforces the requirement for minimum safe distances between the pit latrines and all locations used as domestic water sources, in order to avoid waterborne disease outbreaks. The observed occurrence and survival of pathogens in faecal sludge necessitates use of protective gear for safe emptying of pits and treatment of faecal sludge to reduce pathogens prior to disposal of feacal sludge from unlined pit latrines of Kampala slums.

\section{ACKNOWLEDGEMENTS}

This study was financed through the Sanitation Research Fund for Africa (SRFA) project that was co-funded by the Water Research Commission (South Africa) and the Bill \& Melinda Gates Foundation. Kampala Capital City Authority (KCCA) and Uganda National Council for Science and Technology (UNCST) are acknowledged for the permission granted to carry out this research.

\section{REFERENCES}

AFRICAN WATER FACILITY (2012) Republic of Uganda - Kawempe Urban Poor Sanitation Improvement Project (KUPSIP). Appraisal Report. African Water Facility, Kampala.

APHA (1990) Standard Methods for the Examination of Water and Wastewater ( $11^{\text {th }}$ edn). APHA, New York.

APHA (1995) Standard Methods for the Examination of Water and Wastewater (19 ${ }^{\text {th }}$ edn). APHA, New York.

AUSTIN A (2001) Health aspects of ecological sanitation. In: Proceedings of the $1^{\text {st }}$ International Conference on Ecological Sanitation, 5-8 November 2001, Nanning, China. 104-111.

BAKARE BF, FOXON KM, BROUCKAERT CJ and BUCKLEY CA (2012) Variation in VIP latrine sludge contents. Water SA 38 (4) 479-486. https://doi.org/10.4314/wsa.v38i4.2

BROUCKAERT C, FOXON K and WOOD K (2013) Modelling the filling rate of pit latrines. Water SA 39 (4) 555-562. https://doi. org/10.4314/wsa.v39i4.15

BUCKLEY CA, FOXON KM, BROUCKAERT CJ, RODDA N, NWANERI C, BALBONI E, COUDERC A and MAGAGNA D (2008) Scientific support for the design and operation of ventilated improved pit latrines (VIPs) and the efficacy of pit latrine additives. WRC Report No.TT 357/08. Water Research Commission, Pretoria.

CHAGGU EJ (2004) Sustainable environmental protection using modified pit-latrines. PhD thesis, Wageningen University, The Netherlands.

COFIE OO, AGBOTTAH S, STRAUSS M, ESSEKU H, MONTANGERO A, AWUAH E and KONE D (2006) Solidliquid separation of faecal sludge using drying beds in Ghana: Implications for nutrient recycling in urban agriculture. Water Res. 40 (1) 75-82. https://doi.org/10.1016/j.watres.2005.10.023

DZWAIRO B, HOKO Z, LOVE D and GAZHA E (2006) Assessment of the impacts of pit latrines on groundwater quality in rural areas: A case study from Marondera District, Zimbabwe. Phys. Chem. Earth 31 779-788. https://doi.org/10.1016/j.pce.2006.08.031

HAWKSWORTH D, ARCHER C, RAJCOOMAR K, BUCKLEY C and STENSTRÖM TA (2010) The effect of temperature and relative humidity on the viability of Ascaris Ova in urine diversion waste. Pollution Research Group, University of KwaZulu-Natal, Durban.

HAWKSWORTH DJ, ARCHER C, APPLETON CC, RODDA N and SMITH m (2005) The development of a method to recover Ascaris 
ova from urine diversion toilets. Pollution Research Group, University of KwaZulu-Natal, Durban.

HÖGLUND C (2001) Evaluation of microbial health risks associated with the reuse of source-separated human urine. Doctoral thesis, Royal Institute of Technology (KTH) Department of Biotechnology, Applied Microbiology, Swedish Institute for Infectious Disease Control (SMI) Department of Water and Environmental Microbiology, Stockholm, Sweden.

HOLM RH, TEMBO JM and THOLE B (2015) A comparative study of faecal sludge management in Malawi and Zambia: Status, challenges and opportunities in pit latrine emptying. Afr. J. Environ. Sci. Technol. 9 (11) 783-792. https://doi.org/10.5897/ AJEST2015.1971

KATUKIZA AY, RONTELTAP M, NIWAGABA CB, KANSIIME F and LENS PNL (2010) Selection of sustainable sanitation technologies for urban slums - A case of Bwaise III in Kampala, Uganda. Sci. Total Environ. 409 (1) 52-62. https://doi.org/10.1016/j. scitotenv.2010.09.032

KIBIKYO EM and KAKEMBO F (2010) Contemporary issues and challenges related to water, health, and environment in Uganda. URL: http://www.inweh.unu.edu/Health/Another\%20Drop\%20 presentations/Edward\%20Mukooza\%20Kibikyo\%20and\%20 Frederick\%20Kakembo\%20October.pdf. (Accessed 12 February 2016).

KIMULI D, ZZIWA A, BANADDA N, KABENGE I, KIGGUNDU $\mathrm{N}$, KAMBUGU R, WANYAMA J, TUMUTEGYEREIZE $P$ and KIGOZI J (2016) Quantification of physico-chemical characteristics and modelling faecal sludge nutrients from Kampala City slum pit latrines. Int. J. Res. Eng. Adv. Technol. 3 (6) 129-141.

KULABAKO NR, NALUBEGA m and THUNVIK R (2007) Study of the impact of land use and hydrogeological settings on the shallow groundwater quality in a peri-urban area of Kampala, Uganda. Sci. Total Environ. 381 (1) 180-199. https://doi.org/10.1016/j. scitotenv.2007.03.035

KULABAKO R (2005) Analysis of the impact of anthropogenic pollution on shallow ground water in peri-urban Kampala. PhD thesis, Royal Institute of Technology, Sweden.

MARA D (1996) Low-Cost Urban Sanitation. John Wiley \& Sons, Leeds.

NWANERI CF (2009) Physico-chemical characteristics and biodegradability of contents of ventilated improved pit latrines in eThekwini Municipality. MSc dissertation, School of Biological and Conservation Science. University of KwaZulu-Natal.

PEASEY, A (2000) Health Aspects of Dry Sanitation with Waste Reuse, WELL Studies in Water and Environmental Health, Task No. 324, London School of Hygiene and Tropical Medicine, London

PECSON BM, BARRIOS JA, JIMÉNEZ BE and NELSON KL (2007) The effects of temperature, $\mathrm{pH}$ and ammonia concentration on the inactivation of Ascaris eggs in sewage sludge. Water Res. 41 2893-2902. https://doi.org/10.1016/j.watres.2007.03.040

RADFORD JT and FENNER RA (2013) Characterization and fluidization of synthetic pit latrine sludge. J. Water Sanit. Hyg. Dev. 3 (3) 375-382. https://doi.org/10.2166/washdev.2013.023

ROSE C, PARKER A, JEFFERSON B and CARTMELL E (2015) The characterization of faeces and urine: A review of the literature to inform advanced treatment technology. Crit. Rev. Environ. Sci. Technol. 45 (17) 1827-1879. https://doi.org/10.1080/10643389.2014.1000761 SHERPA AM, BYAMUKAMA D, ROSHAN RS, RAIMUND H,
ROBERT LM and ANDREAS HF (2009) Use of faecal pollution indicators to estimate pathogen die off. J. Water Health 7 (1) 97-107. https://doi.org/10.2166/wh.2009.149

SORENSEN JPR, SADHU A, SAMPATH G, SUGDEN S, DUTTA GUPTA S, LAPWORTH DJ, MARCHANT BP and PEDLEY S (2016) Are sanitation interventions a threat to drinking water supplies in rural India? An application of tryptophan-like fluorescence. Water Res. 88 923-932. https://doi.org/10.1016/j. watres.2015.11.006

STILL D and FOXON K (2012) Tackling the challenges of full pit latrines, Volume 1: Understanding sludge accumulation in VIPs and strategies for emptying full pits. WRC Report No. 1745/1/12. Water Research Commission, Pretoria.

STILL DA and NASH SR (2002) Groundwater contamination due to pit latrines located in a sandy aquifer. A case study from Maputal and Dorpspruit. Partners in Development, Pietermaritzburg.

STRANDE L, RONTELTAP $\mathbf{m}$ and BRDJANOVIC D (eds) (2014) FAECAL Sludge Management: Systems Approach for Implementation and Operation. IWA Publishing, London. $114 \mathrm{pp}$. https://doi.org/10.26530/OAPEN_578132

THYE YP, TEMPLETON MR and ALI m (2009) Pit latrine emptying: technologies, challenges and solutions. Department of Civil and Environmental Engineering, Imperial College London and Practical Action, UK.

TRADING ECONOMICS STATISTICS (2010) Urban population in Uganda. URL: http://www.tradingeconomics.com/uganda/urbanpopulation-wb-data.html (Accessed 18 May 2014).

UGANDA BUREAU OF STATISTICS (2014) National Housing and Population Census, Provisional Results. UBOS, Kampala, Uganda. URL: http://www.ubos.org/2014/11/28/national-population-andhousing-census-2014-provisional-results/ (Accessed 15 October 2015).

UN-HABITAT (2010) Climate Change Assessment for Kampala, Uganda: A Summary. URL: https://www.google.com/webhp?sou rceid $=$ chromeinstant\&ion $=1 \&$ espv $=2 \&$ ie $=U$ UTF- $8 \#$ (Accessed 31 March 2016).

USEPA (United States Environmental Protection Agency) (1994) Guide to Septage Treatment and Disposal. Document EP/625/R-94/002. USEPA, Washington D.C.

WATER AND SANITATION PROGRAM (2012) Economic Impacts of Poor Sanitation in Africa: a case study of Uganda. URL: http:// www.zaragoza.es/contenidos/medioambiente/onu/825-eng-v14.pd (Accessed 15 October 2015).

WHO and UNICEF (World Health Organization and United Nations Children's Fund (2015) Progress on Sanitation and Drinking Water - 2015 update and MDG assessment. WHO, Geneva.

YOKE PT, TEMPLETON $m$ and MANSOOR A (2009) Pit latrine emptying; technologies, challenges and solutions. Paper presented at: EWB-UK Research Conference, London, 20 February 2009. The Royal Academy of Engineering, London.

ZZIWA A, KABENGE I, KAYONDO H, LUGALI Y, KAMBUGU RK and WANYAMA J (2016) Fractional content of non-feacal matter and its contribution to filling rates of pit latrines in Kampala slums. Global J. Eng. Sci. Res. Manage. 3 (2) 36-45.

ZZIWA A, KABENGE I, KIGOZI J, TUMUTEGYEREIZE P and KYEYUNE KR (2014) Baseline household survey report on pit latrine use and management practices in Kampala City. Unpublished report. Makerere University, Kampala. 